\title{
Research boost blocked in Czech universities
}

Prague. Attempts to guarantee academic freedom in Czech universities have had the unintended effect of hindering efforts to boost research by encouraging resistance to government-backed reforms. Now the government is planning new moves to overcome the deadlock, and thus reach a goal that is widely accepted but is yet to be achieved.

In communist times, teaching and research were kept strictly separate. Universities were required to concentrate on the former, and lost most of their scientific activities to the research institutes of the

The post-communist regime - and, indeed, the whole academic community, both inside and outside the universities - is keen to reverse this situation. But attempts to stimulate the growth of research in universities have met with surprising resistance.

Paradoxically, the main stumbling-block has been the universities' newly established autonomy, guaranteed by a law passed in 1990. The universities are now strongly opposed to anything perceived as state interference in their affairs; and their autonomy Czech Academy of Sciences.

has allowed them to fend off pressure for structural reform.

For example, apart from the loss of some of the youngest and most talented academics to private enterprise, there has been no significant turnover in university staff since the new regime came to power in the socalled "velvet revolution". This is despite the fact that many appointments in communist times were made on political grounds rather than because of academic merit.

According to Stanislav Hanzl, rector of the Technical University of

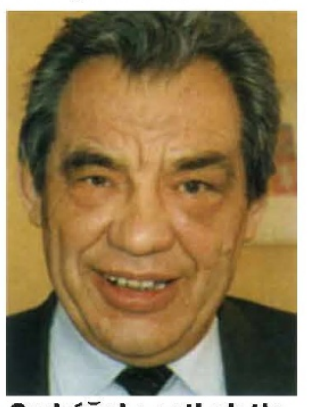

Ondráček: optimistic for the future.
Prague and president of the Czech Rectors' Conference, the heads of university departments - who hold full responsibility for their staff - have accepted in principle that the competence of each academic should be reviewed. But in practice they have found it

\section{'Ecotourism' plans come under fire}

Moscow. Leading Russian scientists have criticized plans announced by the government of President Boris Yeltsin to encourage state-operated nature reserves to engage in commercial operations, for example generating income through admission charges for visitors and even allowing access for hunters for a fee.

Speaking at a meeting of the Russian Academy of Sciences at the end of last month, biologist Vladimir Sokolov called on his colleagues to oppose the government's plans, arguing that "ecotourism", while appropriate for national parks, could become a major threat to the nation's nature reserves.

Further criticism came from another member of the academy, Vadim Tihomirov, chairman of the academy's reserves committee, who said that he was strongly opposed to policies based on economic rather than environmental arguments. Excessive commercial pressures on the reserves could "lead to their death" he said.

Tihomirov quoted several examples of ways in which nature reserves are already being commercially exploited. In the Il'men mineral reserve in the Urals, for example, rare precious and semiprecious stones are being sold, while in the Caucasian biosphere reserve, a large area has been leased for 25 years to a private company producing plastic shoes.
Tihomirov said that such actions appear to ignore the extent to which the reserves are "eternal information resources" and facilities for measuring the Earth's "ecological temperature". They should be used for scientific research and investigation, "definitely not for commerce", he said.

The main target of the scientists' criticisms has been the new federation minister for environmental protection and natural resources, Viktor DanilovDanilyan, who is an economist by training (his predecessor, Nikolai Vorontsov, is a prominent zoologist and evolutionist).

Danilov-Danilyan was responsible for the decree suggesting the commercialization of the reserves. But attempts to move in this direction are not new; the former Soviet leader Nikita Khrushchev, for example, tried to introduce such a policy, although his efforts were blocked at the time by the actions of the scientific community.

At the same time, Danilov-Danilyan has himself complained that the Russian government is trying to solve its economic problems at the expense of the environment. He told a recent meeting organized by his ministry that 1,700 draft programmes for improving the ecological situation in Russia are at risk due to insufficient financing.

Carl Levitin difficult to bring themselves to sack colleagues, particularly when they had no-one above them in the system to blame.

Last autumn the government, frustrated by the lack of progress, forced the issue by amending the higher education law to put all staff, including professors, on temporary contracts. Everyone will now have to reapply for their jobs when their current contracts end (see Nature 366, 497; 1993). But this move has only increased resentment in the universities. "People are fed up with the constant pressure to compete with one another," says Hanzl.

Autonomy has also given universities control over their budgets. But despite a declared intention to improve support for research, the proportion of the budget allocated to this goal fell from 11 per cent in 1989 to around 6 per cent in 1992. In real terms the cut has been even bigger, as it has taken place at a time when the total budget for universities has fallen in value by nearly three-quarters.

Another problem is that university staff are often poorly qualified. Nearly half of university academics have no research degree, and it has been difficult to establish active research groups in universities without introducing new blood.

But some moves to achieve this have also been rejected. When the Czech Academy of Sciences, for example, was forced last year by budgetary pressures to cut back the work of its research institutes (see Nature $368,386 ; 1994)$, it drew up a list of scientists it could no longer employ, but who, it believed, would be of value to universities.

The government established a $\mathrm{K} c s 100$ million fund to help transfer these scientists into universities. But many universities felt they were being offered low-quality rejects - a charge which the academy denies and as a result barely a quarter of the funds were used.

There is, however, new optimism that things may change soon as a result of recent moves by the government. This year, for example, university budgets include for the first time a component based on research output, rather than student numbers. At present, this component is only 10 per cent of the total budget; but it is planned to rise to about a third over the next few years.

In addition, a new law covering research in universities is scheduled to be introduced late next year. If passed, it will, for example, encourage greater exchange between academy and university scientists. Emanuel Ondrácek, deputy minister in the department of universities and science, is already pleased about the way things are going. "Science has made big progress in the past six months in universities," he says.

Alison Abbott 